\title{
Evaluation of the Genetic Variation of Cowpea Landraces (Vigna unguiculata) from Western Cameroon Using Qualitative Traits
}

\author{
Toscani NGOMPE-DEFFO ${ }^{1}$, Eric Bertrand KOUAM ${ }^{1 *}$, \\ Honoré BEYEGUE-DJONKO ${ }^{1}$, Mariette ANOUMAA ${ }^{2}$
}

\author{
${ }^{1}$ University of Dschang, Faculty of Agronomy and Agricultural Science, Department of Crop Science, PO Box 222 Dschang, \\ Cameroon; toscani.ngompe@yahoo.fr; ericbkouam@yahoo.com (*correspondingauthor);beyeguehon@yahoo.fr \\ ${ }^{2}$ University of Dschang, Faculty of Science, Department of Plant Biology, PO Box 67 Dschang, Cameroon; mariettanou@yahoo.fr
}

\begin{abstract}
Characterization of the genetic diversity and analysis of the genetic relationship between accessions of a crop species is a key step in breeding superior cultivars. The main objective of the hereby study was to determine the genetic variation between 30 cowpea accessions collected throughout the eight divisions of the Western Region of Cameroon using qualitative traits. Phenotypic variation of these accessions was evaluated using diversity indices and cluster analyses. A total of twenty qualitative traits were used for the study. Fifteen of them (75\%) were polymorphic, displaying each at least two phenotypic classes. The monomorphic characters were growth pattern, leaf color, leaf hairiness, plant hairiness and pod hairiness, each with only one phenotypic class. Results showed a relatively significant level of genetic diversity among the studied cowpea accessions. Overall, the average of the observed and effective number of phenotypic classes per qualitative trait were $\mathrm{Na}=2.350$ and $\mathrm{Ne}=1.828$ respectively. The Nei's genetic diversity and the Shannon weaver diversity index were $\mathrm{He}=0.369$, ranging from zero (monomorphic trait) to 0.655 (growth habit) and $\mathrm{H}^{\prime}=0.609$, ranging from zero (monomorphic trait) to 0.996 (seed crowding), respectively. The dendrogram constructed from the twenty qualitative traits revealed 05 accessions clusters with the number of accessions in each cluster varying from one to eleven. Information obtained from this study is likely be useful for future cowpea breeding program.
\end{abstract}

Keywords: genetic variation, phenotypic class, qualitative trait, Vigna unguiculata

\section{Introduction}

Cowpea, Vigna unguiculata $(L$.) Walps is an important food legume in developing countries, mostly in sub-Saharan Africa, Asia, Central and South America (Singh et al., 1997). Cowpea has been referred to as "poor man's meat" because of its high protein content (20-25\%) (Diouf and Hilu, 2005; Kereen and Taiwo, 2007; Sharmar et al., 2013). Cowpea young leaves, pods and peas contain vitamins and minerals useful for human consumption and animal feeding (Rachie, 1985; Nielsen et al., 1997). This crop tolerates low soil fertility due to its high rate of nitrogen fixation (Eloward and Hall, 1987). Because of its high capacity to cover the ground, this legume is also used to control soil erosion (Kariaga, 2004). Sub-Saharan Africa accounts for the majority (more than 64\%) of the world's cowpea production, which is estimated to about 12.5 million tons (Langyintuo et al., 2003).

In Cameroun, the Far North Region is the largest contributor to the national production of cowpea and the crop ranks second after groundnuts in the category of leguminous crop (Dudje et al., 2009). The production in this region ranges from 300 to $500 \mathrm{~kg} / \mathrm{ha}$ in farmers' fields and 1,200 to $2,000 \mathrm{~kg} / \mathrm{ha}$ in research stations (Dudje et al., 2009). According to Bidima (2012), the national annual production in Cameroon is estimated to about 110,000 tons from a planted area of 105,000 hectares. The three northern regions of Cameroon (Adamaoua, North and Far North) account for about 90,000 tons of the national production (Bidima, 2012).

Despite the low contribution of the West Region to the national production, cowpea is a commodity of high market, cultural and economic value due to its high local consumption and cultural considerations (Mbiendou, 2012). The market price of cowpea in the West Region is almost the double of that of Northern Cameroon (Mbiendou, 2012). Despite its importance, the principal constraints to the production of this legume is the lack of the high yielding improved varieties, resistant to the abiotic and biotic stresses among which diseases and insects pests are the most prevalent (Nkamleu et al., 2000). 
The loss of genetic diversity, due to conventional breeding modern agricultural practices that promote monoculture has been dramatic for many cultivated species (Wilkes, 1983). As a better performing crop varieties are released by research institutions and agencies, farmers are encouraged to adopt the latter by extension services because of their higher profitability. This shift will result to the abandon of landraces and loss of genetic diversity. A consequence of this is the increase vulnerability to biotic and abiotic stress of the elite germplasm due to a narrowing genetic base of the crop. The knowledge, the access and the use of the available diversity in domesticated and wild relatives of a plant are essential for sustainable crop improvement (Singh, 2001). Assessing and maintaining genetic diversity are therefore central to ensure more prospects in breeding of cowpea and other plant species (St.Clair and Howe, 2011).

Because of their direct observation on plants during the vegetative and reproductive stages, phenotypic qualitative traits have been widely used to assess genetic variability between accessions in cowpea and other plant species (Bennet-Lartey and Ofori, 1999; Geleta and Labuuschagne, 2005; Ofori et al., 2006). In Cameroon, the lack of detailed information on the genetic diversity of cowpea limits the understanding of its genetic structure and evolution. This lack also hampers the achievements in breeding of this legume plant. The present investigation was therefore undertaken to assess the extent of the genetic variation available in cowpea accessions examined in order to assist in setting up a breeding program for cowpea improvement.

\section{Materials and Methods}

\section{Plant materials and studysite}

Cowpea landraces were collected from all the eight divisions of the Western Region of Cameroon. Accessions were collected from market places, farmers' fields and at the Institute of Agricultural Research for Development. A total of 30 accessions were used for the study. The study was carried out at the Research and Teaching farm of the Faculty of Agronomy and Agricultural Sciences of the University of Dschang, located in the West Region of Cameroon at latitude of $5^{\circ} 20^{\prime}$ North and longitude of $10^{\circ} 05^{\prime}$ East, and $1407 \mathrm{~m}$ above the sea level. The annual rainfall of the study site ranges from 1,800 to $2,000 \mathrm{~mm}$.
The average annual temperature and relative humidity are closed to $20.50^{\circ} \mathrm{C}$ and $76.8 \%$, respectively.

\section{Experimental design}

The thirty accessions were sown in the field under rainfed conditions from August to December 2016 in a randomized complete block design (RCBD) with three replications, on a total area of $2000 \mathrm{~cm} \times 1980 \mathrm{~cm}$. The blocks of $600 \mathrm{~cm} \times 2000 \mathrm{~cm}$ were outdistanced of $90 \mathrm{~cm}$ from each other. Each block consisted of 30 experimental units of $200 \mathrm{~cm} \times 200 \mathrm{~cm}$, for each of the 30 accessions to evaluate. Each experimental unit comprised 16 plants distant to each other of $50 \mathrm{~cm}$ within the lane and the row in order to avoid competition among neighboring plants and to ensure a sound establishment of accessions. Four plants were sampled at the center of each experimental unit populated with sixteen individuals for qualitative scoring. A total of 12 plants per accessions were analyzed. Agronomic and plant protection practices were applied to provide plants with adequate growing conditions. Plants were evaluated for twenty qualitative traits at various stages of development.

\section{Evaluated qualitative traits}

In order to categorize each accession morphologically, data on twenty traits were recorded according to International Board for Plant Genetic Resources descriptors for cowpea (IBPGR, 1983). Table 1 presents the 20 qualitative traits, their codes and their description classes used in the analysis. Each accession was scored for the most frequent character shown in each qualitative trait.

\section{Data analysis}

Phenotypic frequency distributions of the characters were worked out for all the sample germplasm and were established using GrahPad Prism 6.0. To assess the overall phenotypic diversity of each character for all accessions, the observed $(\mathrm{Na})$ and the expected $(\mathrm{Ne})$ number of phenotypic classes were calculated. Phenotypic classes' frequencies were used to compute Nei's (1987) gene diversity $(\mathrm{He})$ and Shannon-Weaver diversity index $\left(\mathrm{H}^{\prime}\right)$. The Nei's gene diversity was calculated as follow: $\mathrm{He}=1-\sum_{\mathrm{i}=1}^{\mathrm{n}} x_{i}^{2}$

Table 1. List of qualitative traits used in this study and observed description classes

\begin{tabular}{|c|c|c|c|}
\hline No & Qualitative trait name & Code & Description classes \\
\hline 1 & Flower colour & Fcol & Violet (2), Mauve-pink (3) \\
\hline 2 & Growth habit & GH & Erect (2), Semi-erect (3), Semi-prostrate (5), Prostrate (6), Climbing (7) \\
\hline 3 & Growth pattern & GP & Indeterminate (2) \\
\hline 4 & Immature pod pigmentation & IPP & None (0), Pigmented tip (1), Uniformly pigmented (5) \\
\hline 5 & Leaf "V" marking & Mark"V" & Present (1), Absent (0) \\
\hline 6 & Leaf colour & LCol & Dark green $(7)$ \\
\hline 7 & Leaf texture & LT & Intermediate (2), Membranous (3) \\
\hline 8 & Leaf hairiness & LH & Glabrescent (5) \\
\hline 9 & Plant hairiness & $\mathrm{PH}$ & Glabrescent (3) \\
\hline 10 & Plant pigmentation & PP & Very slight (1), Moderate (3), Extensive (7) \\
\hline 11 & Pod attachment to peduncle & PAP & $30^{\circ}-90^{\circ}$ down from erect (5), Erect (7) \\
\hline 12 & Pod curvature & PC & Straight (0), Slightly curved (3), Curved (5) \\
\hline 13 & Pod hairiness & PodH & Glabrescent (3) \\
\hline 14 & Raceme position & $\mathrm{RP}$ & Mostly above canopy (1), In upper canopy (2), Throughout canopy (3) \\
\hline 15 & Seed colour & SCol & White pale (1), Cream (2), Cream grey spotted (3), Cream brown spotted (4) \\
\hline 16 & Seed crowding & SCrow & Semi-crowded (3), Crowded (5) \\
\hline 17 & Seed shape & SS & Kidney (1), Ovoid (2), Rhomboid (5) \\
\hline 18 & Terminal leaflet shape & TLS & Sub-globose (2), Sub-hastate (3), Hastate (4) \\
\hline 19 & Testa texture & TT & Smooth (1), Smooth to rough (3) \\
\hline 20 & Twinning tendency & TwT & None (0), Slight (3), Pronounced (7) \\
\hline
\end{tabular}


510

The Shannon-Weaver diversity index was estimated as suggested by Hennink and Zeven (1991) using the formula: $\mathrm{H}^{\prime}=-\sum_{\mathrm{i}=1}^{\mathrm{n}} x_{i} \ln \left(x_{i}\right) / \ln (n)$

Where ' $x_{i}$ ' represents the relative frequency of the ' $i^{\text {th' }}$ class of a trait and ' $n$ ' represents the number of phenotypic classes of the trait.

Minimum and maximum values for the diversity indices $\left(\mathrm{He}\right.$ and $\left.\mathrm{H}^{\prime}\right)$ are 0 and 1 respectively. Value of zero indicates a monomorphic character with all the individuals belonging to the same category and having the same phenotypic class. $\mathrm{He}$ or H'equal to one specifies maximum diversity with individuals equally dispersed among the different phenotypic classes of the character. The coefficient of dissimilarity was computed for all the pairwise comparisons of accessions using XLSTAT, version 2014.5.0. and a dendrogram was created by cluster analysis with Agglomerative Hierarchical Clustering (AHC) using the same XLSTAT computer program.

\section{Results}

\section{Genetic diversity}

Of the twenty qualitative traits presented in Table 1 , five traits (25\%) were monomorphic (growth pattern, leaf colour, leaf hairiness, plant hairiness and pod hairiness) whereas fifteen traits (75\%) were polymorphic.

Among the fifteen polymorphic traits, six traits were polymorphic with two phenotypic classes (leaf texture, "V" leaf marking, flower colour, testa texture, seed crowding and pod attachment to peduncle). Concerning the leaf texture (Fig. 1A), membranous texture was the dominant leaf texture observed $(80 \%)$ over all the studied accessions as opposed to intermediate (20\%). With regard to "V" leaf marking distribution it was observed that $63 \%$ of the accessions studied presented the "V" mark at the upper face of their leaves and $37 \%$ of the accessions do not present any "V" mark (Fig. 1B). Flower colour of cowpea accessions analyzed was either violet or violet-pink. Most accessions had violet flowers (80\%), while violet-pink flowers were on $10 \%$ of accessions (Fig. 1C). The testa texture of the $67 \%$ of the accessions studied was smooth, while $33 \%$ of these accessions had smooth to rough testa texture (Fig. 1D). It was observed that $53 \%$ of the studied accessions produced crowded seed and $47 \%$ of accessions were semi-crowded (Fig. 1E). In the study, two classes of pod attachment to peduncle were observed (Fig. 1F), whereas $87 \%$ of the accessions studied were 30-90 down from erect and 13\% showed erect pod attachment to peduncle.

Seven characters were polymorphic with three phenotypic classes (plant pigmentation, pod curvature, terminal leaflet shape, seed shape, immature pod pigmentation, raceme position and twinning tendency). Out of the accessions studied, $57 \%$ showed very slight plant pigmentation, 23\% showed moderate plant pigmentation and $20 \%$ of the accessions showed extensive plant pigmentation (Fig. 1G). The general trend of pod curvature is that $57 \%$ of the accessions had pods slightly curved, while $23 \%$ of the accessions had curved pods and $20 \%$ had straight pod curvature (Fig. $1 \mathrm{H})$. It was observed that $53 \%$ of the accessions studied produced a globose terminal leaflet shape and $43 \%$ were sub-hastate terminal leaflet shape. Only 3\% of the accessions studied showed hastate terminal leaflet shape (Fig. 1I). Among the five main seed shape descriptor described by the International Board for Plant Genetic Resources IBPGR (1983) for cowpea, three seed shape were observed (Fig. 1J) as follow: 60\% of the studied accessions showed kidney seed shape, while $37 \%$ had rhomboid seed shape. Only $3 \%$ of the accessions studied had an ovoid seed shape. The distribution of pigmentation in immature pods of cowpea accessions studied was as follow: 63\% of accessions had no pigmentation (green pods), 20\% had pigmented tips, and $17 \%$ had splashes of pigment left throughout the surface of the immature pods (Fig. 1K).

The distribution of raceme position of the studied cowpea accessions showed that $43 \%$ of the accessions had their raceme positions at the same level as the canopy, while $40 \%$ of the accessions produced racemes within the canopy and only $17 \%$ had their raceme positions above the canopy (Fig. 1L). Three categories of twining tendency in the cowpea accessions studied were observed: $47 \%$ of accessions studied showed pronounced twining tendency, while 43\% had slight twining tendency. $10 \%$ of the accessions studied had no twining tendency (Fig. 1M).

Concerning the distribution of seed color in the cowpea accessions studied, four categories were observed (Fig. 1N). $50 \%$ had cream seed color, while $27 \%$ produced white pale seed color. The two others categories of seed color, less represented were cream grey spotted observed on $13 \%$ of accessions and cream brown spotted observed on $10 \%$ of the accessions analyzed. It was observed that $50 \%$ of the studied accessions displayed secondary branches which form acute angles with main stem, producing an erect growth habit. A ratio of $13.33 \%$ of accessions was semi-erect, $27 \%$ of accessions had semi-prostrate growth habit and 3\% showed prostrate growth habit. Seven percent of accessions showed climbing growth habit, needed stalk to twin on (Fig. 1O).

The observed number of phenotypic classes ranges from 1 (monomorphic trait) to 5 (growth habit) with a mean of 2.530 for all the twenty traits (Table 2). The mean effective number of phenotypic classes was $\mathrm{Ne}=1.828$, with values ranging from 1 (monomorphic trait) to 2.901 (growth habit). The mean Nei's gene diversity and Shannon Weaver diversity index were 0.369 and 0.609 respectively (Table 2). Nei's gene diversity ranged from zero (monomorphic trait) to 0.655 (growth habit) and Shannon Weaver diversity index ranged from zero (monomorphic trait) to 0.996 (seed crowding) (Table 2)

\section{Cluster analysis}

The Cluster analysis with UPGMA using dissimilarity coefficient resulted in the identification of five groups of accessions as shown by the dendogram (Fig. 2). The number of accession in each cluster varied from one (Cluster 5) to eleven (Cluster 4) (Table 3). Cluster 4 was the largest and consisted of eleven accessions. In this group, accessions have predominantly erect pod attachment to peduncle; kidney and ovoid seed shape; sub-hastate and hastate terminal leaflet shape (Table 4). The second largest group is the cluster 1 made of ten accessions. This cluster is characterized by an erect and semi-erect growth habit; a raceme located mostly above and in upper the canopy; they have rhomboid seed shape. The cluster 2 consists of five accessions and is singularized by extensive plant pigmentation; erect pod attachment to peduncle and have a pronounced twinning tendency (Table 4). Cluster 3 is made of tree accessions having predominantly " $V$ " leaf marking and a sub-hastate terminal leaflet shape. Only one accession (KEB-CP039) 
Table 2. Diversity parameters of phenotypic qualitative traits in cultivated Vigna unguiculata

\begin{tabular}{|c|c|c|c|c|}
\hline Qualitative trait name & $\mathrm{Na}$ & $\mathrm{Ne}$ & $\mathrm{He}$ & $\mathrm{H}^{\prime}$ \\
\hline Flower colour & 2 & 1.219 & 0.180 & 0.469 \\
\hline Growth habit & 5 & 2.901 & 0.655 & 0.784 \\
\hline Growth pattern & 1 & 1.000 & 0.000 & 0.000 \\
\hline Immature pod pigmentation & 3 & 2.134 & 0.532 & 0.828 \\
\hline Leaf "V" marking & 2 & 1.873 & 0.466 & 0.951 \\
\hline Leaf colour & 1 & 1.000 & 0.000 & 0.000 \\
\hline Leaf texture & 2 & 1.471 & 0.320 & 0.722 \\
\hline Leaf hairiness & 1 & 1.000 & 0.000 & 0.000 \\
\hline Plant hairiness & 1 & 1.000 & 0.000 & 0.000 \\
\hline Plant pigmentation & 3 & 2.393 & 0.582 & 0.892 \\
\hline Pod attachment to peduncle & 2 & 1.301 & 0.231 & 0.567 \\
\hline Pod curvature & 3 & 2.406 & 0.584 & 0.895 \\
\hline Pod hairiness & 1 & 1.000 & 0.000 & 0.000 \\
\hline Raceme position & 3 & 2.662 & 0.624 & 0.935 \\
\hline Seed colour & 4 & 2.866 & 0.651 & 0.864 \\
\hline Seed crowding & 2 & 1.991 & 0.498 & 0.996 \\
\hline Seed shape & 3 & 2.018 & 0.504 & 0.717 \\
\hline Terminal leaflet shape & 3 & 2.113 & 0.527 & 0.738 \\
\hline Testa texture & 2 & 1.799 & 0.444 & 0.918 \\
\hline Twinning tendency & 3 & 2.406 & 0.585 & 0.895 \\
\hline Mean & 2.350 & 1.828 & 0.369 & 0.609 \\
\hline Std. Dev. & 1.089 & 0.663 & 0.252 & 0.382 \\
\hline Std. Error of means & 0.244 & 0.148 & 0.059 & 0.086 \\
\hline
\end{tabular}

$\mathrm{Na}=$ Number of observed phenotypic classes; $\mathrm{Ne}=$ Number of effective phenotypic classes. $\mathrm{He}=$ Nei's genetic diversity $; \mathrm{H}^{\prime}=$ Shannon-Weaver diversity index

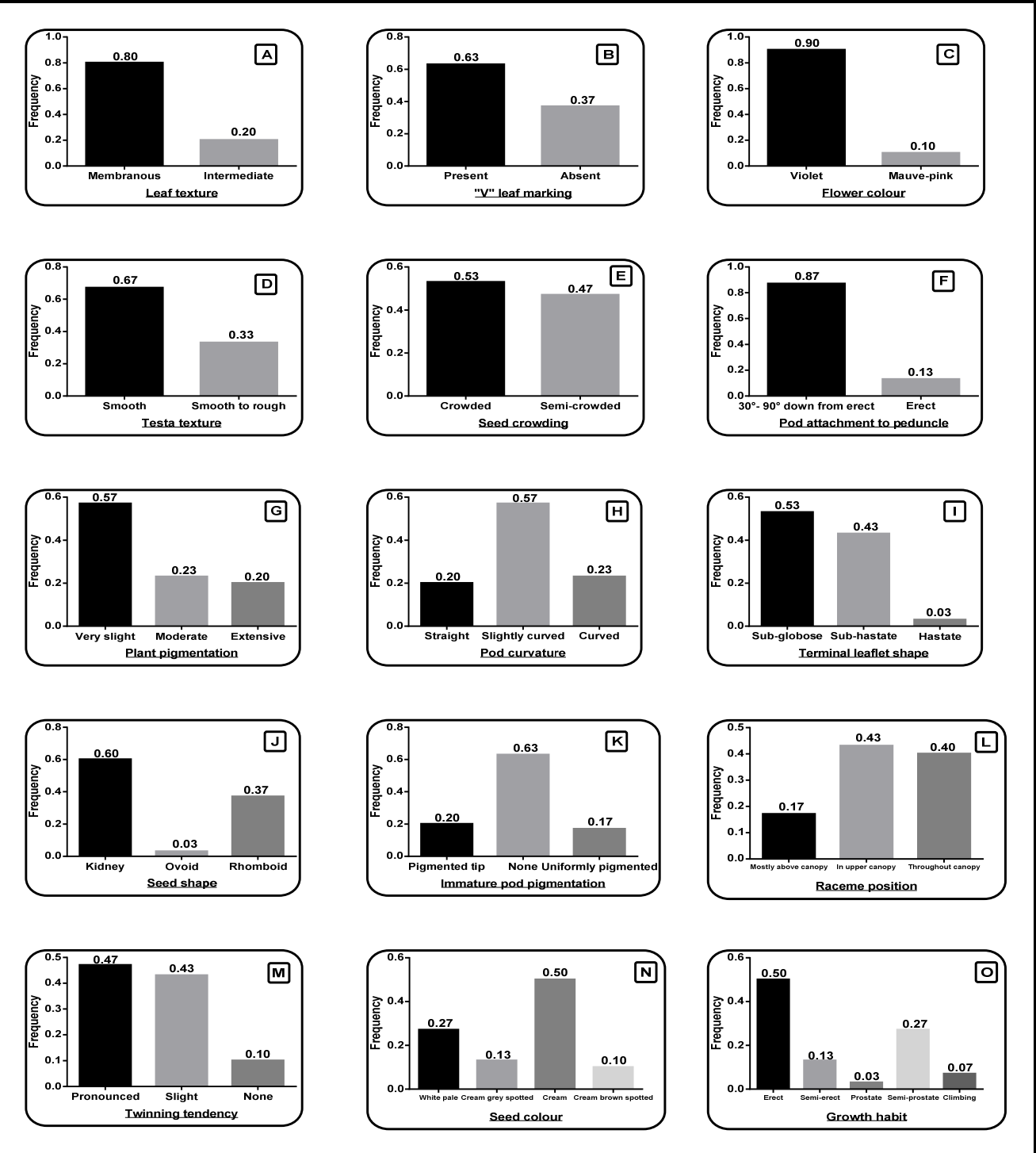

Fig. 1. Phenotypic classes' frequencies of fifteen polymorphic qualitative traits in cultivated Vigna unguiculata from the Western Region of Cameroon 


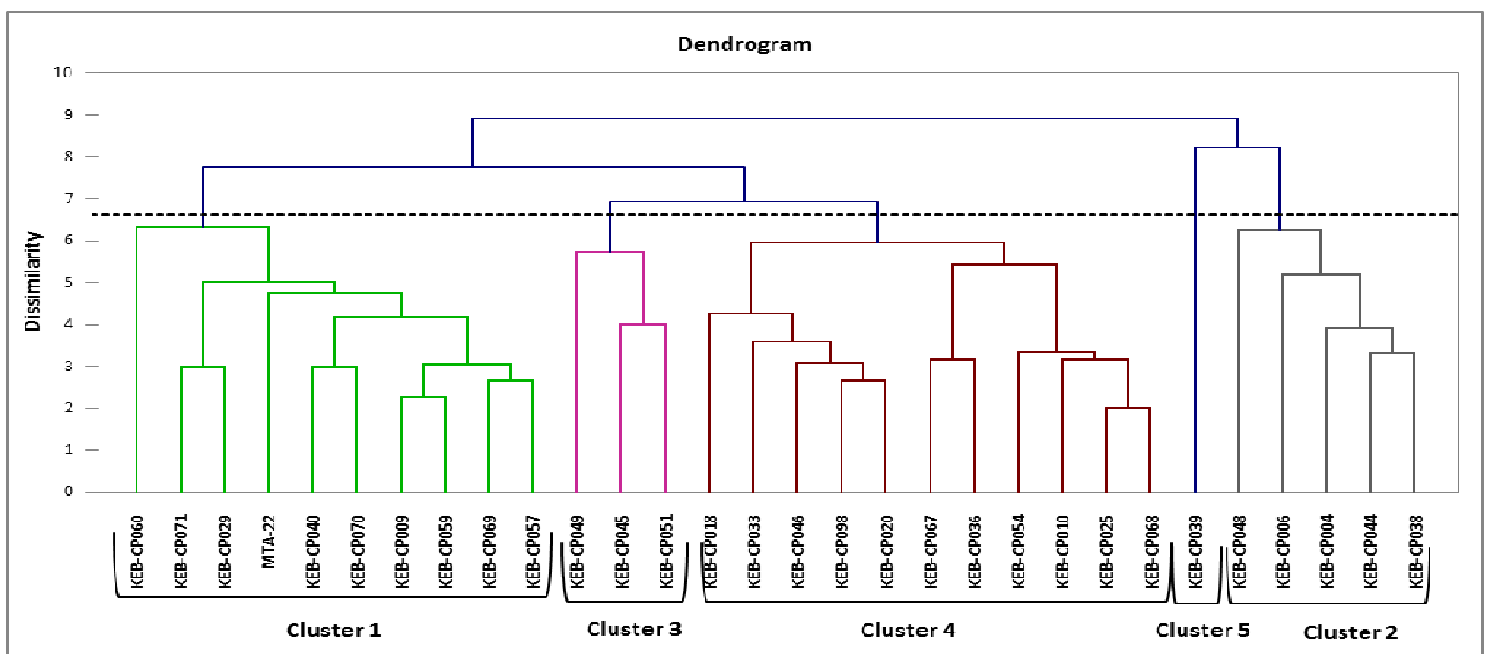

Fig. 2. Phylogenetic relationship between the thirty accessions of cultivated Vigna unguiculata from the Western Region of Cameroon

Table 3. Accessions distribution between clusters based on 19 qualitative traits at cultivated Vigna unguiculata

\begin{tabular}{ccc}
\hline Cluster & Accessions & $\begin{array}{c}\text { Number of } \\
\text { accession }\end{array}$ \\
\hline Cluster 1 & KEB-CP057, KEB-CP009, KEB-CP040, KEB-CP071, KEB-CP069, KEB-CP060, KEB-CP059, KEB-CP070, MTA22, KEB-CP029 & 10 \\
\hline Cluster 2 & KEB-CP006, KEB-CP004, KEB-CP044, KEB-CP038, KEB-CP048 & 5 \\
\hline Cluster 3 & KEB-CP045, KEB-CP049, KEB-CP051 \\
\hline Cluster 4 & KEB-CP018, KEB-CP067, KEB-CP010, KEB-CP025, KEB-CP036, KEB-CP054, KEB-CP046, KEB-CP098, KEB-CP020, KEB-CP068, KEB- & 11 \\
\hline Cluster 5 & CP033 & 3 \\
\hline
\end{tabular}

Table 4. Qualitative characteristics of the different clusters of Vigna unguiculata

\begin{tabular}{|c|c|c|c|c|c|}
\hline Qualitative trait name ${ }^{*}$ & Cluster 1 & Cluster 2 & Cluster 3 & Cluster 4 & Cluster 5 \\
\hline Flower colour & 2 & 2,3 & 2 & 2,3 & 2 \\
\hline Growth habit & 2,3 & $3,5,7$ & 3,5 & $2,3,5,7$ & 6 \\
\hline Growth pattern & 2 & 2 & 2 & 2 & 2 \\
\hline Immature pod pigmentation & $0,1,5$ & $0,1,5$ & 5 & 0,1 & 0 \\
\hline Leaf "V" marking & 0,1 & 0,1 & 1 & 0,1 & 1 \\
\hline Leaf colour & 7 & 7 & 7 & 7 & 7 \\
\hline Leaf texture & 2,3 & 2,3 & 3 & 2,3 & 3 \\
\hline Leaf hairiness & 5 & 5 & 5 & 5 & 5 \\
\hline Plant hairiness & 3 & 3 & 3 & 3 & 3 \\
\hline Plant pigmentation & 1,3 & 7 & 1,3 & 1,3 & 7 \\
\hline Pod attachment to peduncle & 5,7 & 5 & 3 & 5 & 5 \\
\hline Pod curvature & 0,3 & 3,5 & 3,5 & $0,3,5$ & 3 \\
\hline Seed colour & $1,2,4$ & 2,3 & 3,4 & $1,2,4$ & 2 \\
\hline Seed crowding & 3,5 & 3,5 & 3,5 & 3,5 & 3 \\
\hline Pod hairiness & 3 & 3 & 3 & 3 & 3 \\
\hline Raceme position & 1,2 & 2,3 & 1,3 & $1,2,3$ & 2 \\
\hline Seed shape & 5 & 1,5 & 1 & 1,2 & 1 \\
\hline Terminal leaflet shape & $2,3,4$ & 2,3 & 3 & 2,3 & 2 \\
\hline Testa texture & 1,3 & 1,3 & 1,3 & 1,3 & 1 \\
\hline Twinning tendency & 0,3 & 7 & 3,7 & 3,7 & 0 \\
\hline
\end{tabular}

*: Description of each qualitative trait and its classes is given in Table 1

constitutes cluster 5, the only prostrate growth habit accession. It has no twinning tendency.

\section{Discussion}

Scoring qualitative traits appears as an important alternative to molecular and biochemical techniques in assessing genetic variation on plant germsplasm and information on genetic relationship needed in breeding programs. Cowpea in the Western region of Cameroon has a lot of economic and cultural consideration and there was an imperative need for genetic characterization and preservation. For the description and classification of the genetic resources of plant species, morphological characterization appears as the first step (Smith and Smith, 1989). In the present study, divergence among cowpea 
accessions was expressed in term of differences in phenotypic classes. The study indicated a wide distribution of phenotypic classes for the traits considered and showed the presence of numerous genetically distinct accessions in the local collections. Because of the direct observation on plants, qualitative traits are considered as the most significant characters to identify a particular plant accession or variety and can help plant breeders with strategies for the conservation of the genetic diversity. These traits are mostly genetically controlled and are less influenced by environmental factors compared to quantitative traits.

Polymorphism was found in 15 out of 20 qualitative traits studied hereby. Therefore, clear morphological differences exist between the analyzed accessions for $75 \%$ of the studied traits (Table 2). For the overall phenotypic variation in the study, $75 \%$ of phenotypic traits showed significant variation in the cowpea collection. A total of 47 phenotypic classes were detected by the 20 phenotypic traits in our study, which is significantly lower compared to cowpea germplasm in Ghana that found 31 phenotypic classes with only 7 qualitative traits (Cobbinah et al., 2011). However, the results obtained were closed with those of Gonné et al. (2013) who found 9 phenotypic classes from only four qualitative traits in Northern Cameroon. The growth habit of a crop is of high significance to the cropping system. The growth habit of cowpea greatly affects the harvest of the crop (Fery, 1985; Bennett-Lartey and Ofori, 1999). The prostrate types are used by farmers in mixed cropping (Doku, 1970; Rachie and Rawal, 1976). It was reported that the prostrate and climbing types induce extended periods of pod maturation, resulting in an uneven periods of harvesting and specially required bending very low to pick the pods. Aryeetey (1971) and Cobbinah et al. (2011) reported similar observations. Erect and sub-erect plants do not need stalks to keep pods from touching the ground. This prevents rotting of pods, which usually happen when pods come into contact with the soil. This is also in agreement with Cobbinah et al. (2011). All phenotypic classes of the twining tendency documented in the IBPGR (1983) descriptor list for cowpea was observed for the accessions studied. The results indicated that most of the accessions need staking since majority of them show trailing tendency. The pigmentation of the cowpea accession ranged from green (no pigmentation) to purple, with different intensities of the purple coloration. This pigmentation is dependent on the concentration of anthocyanin in the plant part as previously highlighted (Fery, 1985; Harland, 1919).

According to Bennet-Lartey and Ofori (1999), it is more desirable to have racemes above the canopy than either at the same level of the canopy or within the canopy. This position facilitates pod visibility and harvesting. In this study, that character and observation were confirmed when harvesting $17 \%$ of accessions which presented their raceme mostly above the canopy. The results of the flowers color are consistent with those found by Cobbinah et al. (2011), Nkouannessi (2005) and Bennet-Lartey and Ofori (1999) where the violet flowers were largely represented. According to Purseglove (1968) flower colors that are mostly encountered on the field are pink, white and violet. So, in spite of the fact that the results of this study showed only two colors of flowers documented by IBPGR (1983), Gibbon and Pain (1985) reported additional flower colors such as pale blue and yellow, which were not observed in the current study. This may be attributed to the relatively large number of accessions studied as compared to the smaller number used in the present study. In addition to the three shapes observed in this study, Nkouannessi (2005) observed two other shapes: crowder and globose. He also found two other testa textures (rough and wrinkled). This should be attributed to the large number of accessions used. Three types of pod curvature was reported in this study and was similar to those reported by Nkouannessi (2005) who also found some accession with " $V$ " leaf marking as reported in this study. The maximum Nei's genetic diversity value of 0.655 was contributed by growth habit, where 5 different phenotypic classes were identified. This is higher than the reports of Gonné et al. (2013) who reported 3 types of growth habits in 18 cowpea accessions. The hereby results are however lower as compared to 6 phenotypic classes of growth habits reported by Cobbinah et al. (2011) when studying 134 cowpea accessions. The Nei's average genetic diversity value recorded was $\mathrm{He}=0.359$. This result was comparatively higher than that reported in cultivated cowpea using Allozyme markers ( $\mathrm{He}=0.061$; Pasquet, 2000), AFLP markers ( $\mathrm{He}=0.108$; Coulibaly et al., 2002) and RAPD Markers $(\mathrm{He}=0.123$; $\mathrm{Ba}$ et al., 2004). The Shannon-Weaver diversity index found in this study was H' $=0.609$. Similar high values were reported in others cultivated inbred species like rice (Roy et al., 2016) and wheat (Hailu et al., 2010).

\section{Conclusions}

Traditional cowpea landraces from western Cameroon that are highly preferred by consumers because of their taste and cultural considerations needed to be characterized prior to their conservation. The genetic characterization of this crop was based on qualitative phenotypic descriptors. For the trait growth habit, five different phenotypic classes were detected, followed by seed colour with four different phenotypic classes. Growth habit, seed colour, plant pigmentation, pod curvature, raceme position and twinning tendency were the primary determinants for explaining the existing genetic variation in this collection of cowpea genotype. The thirty accessions were grouped in five distinct clusters with varied number of accessions.

\section{References}

Aryeetey AN (1971). Increasing cowpea production in Ghana. The Ghana Farmer 22:386-392

Ba FS, Pasquet RS, Gepts P (2004). Genetic diversity in cowpea [Vigna unguiculata (L.) Walp.] as revealed by RAPD markers. Genetic Resources and Crop Evolution 51:539-550.

Bennet-Lartey SO, Ofori I (1999). Variability studies in some qualitative characters of cowpea (Vigna unguiculata (L.) Walp) accessions from four cowpea- growing regions of Ghana. Ghana Journal of Agricultural Science 32:3-9.

Bidima IM (2012). Haricot niébé: L’or blanc du Sahel. La voix du Paysan Mensuel del'entrepreneur rural.

Cobbinah FA, Addo-Quaye AA, Asante IK (2011). Characterization, evaluation and selection of cowpea (Vigna unguiculata (L.) Walp) 
514

accessions with desirable traits from eight regions of Ghana. ARPN Journal of Agricultural and Biological Science 6(7):21-32.

Coulibaly S, Pasquet RS, Papa R, Gepts P (2002). AFLP analysis of the phenetic organization and genetic diversity of Vigna unguiculata $\mathrm{L}$. Walp. reveals extensive gene flow between wild and domesticated types. Theoretical and Applied Genetics 104:358-366.

Diouf, D, Hilu KW (2005). Microsatellites and RAPD markers to study genetic relationships among cowpea breeding lines and local varieties in Senegal, Genetic Resources and Crop Evolution 52(8):1057-1067.

Doku EV (1970). Variability in local and exotic varieties of cowpea (Vigna unguiculata (L.) Walp:) in Ghana. Ghana Journal of Agricultural Science 3:139-143.

Dugje IY, Omoigui LO, Ekeleme F, Kamara AY, Ajeigbe H (2009). Production du niébé en Afrique de lOuest : guide du paysan, IITA, Ibadan, Nigeriapp 20.

Eloward HOA, Hall AE (1987). Influence of early and late nitrogen fertilization on yield and nitrogen fixation of cowpea under well-watered and dry field conditions. Field Crops Research 15:229-244.

Fery RL (1985). Improved cowpea cultivars for the horticultural industry in the USA, In: Singh SR, Rachie KO (Eds). Cowpea Research, Production and Utilization.John Wiley and Sons, U.Kpp 129-135.

Geleta N, Labuschagne MT (2005). Qualitative traits variation in sorghum (Sorghum bicolor (L.) Moench) germplasm from, eastern highlands of Ethiopia, Biodiversity and Conservation 14(13):3055-3064.

Gibbon D, Pain A (1985). Crops of the Drier Regions of the Tropics. London:Longmans.

Gonné S, Venasius WL, Laminou A (2013). Characterization of some traditional cowpea varieties grown by farmers in the Soudano-Sahelian zone of Cameroon. International Journal of Agriculture and Forestry 3(4):170-177.

Hailu F, Johansson E, Merker A (2010). Patterns of phenotypic diversity for phonologic and qualitative traits in Ethiopian tetraploid wheat germplasm. Genetic Resources and Crop Evolution 57:781-790.

Harland SC (1919). Inheritance of certain characters in the cowpea (Vigna sinensis).Journal of Genetics 8:101-132.

Hennink S, Zeven AC (1991). The interpretation of Nei \& ShannonWeaver within population variation indices. Euphytica 51:235-240.

International Board for Plant Genetic Resources (1983). Cowpea descriptors. IBPGR, Rome.

Kareem KT, Taiwo MA (2007). Interactions of viruses in cowpea: effects on growth and yield parameters. Virology Journal 4:15-21.

Kariaga BM (2004). Intercropping maize with cowpeas and beans for soil and water management in western Kenya, $13^{\text {th }}$ International Soil Conservation Organisation Conference, PaperNo. 993 pp 5.

Langyintuo AS, Lowenberg-DeBoer J, Faye M, Lambert D, Ibro G, Moussa B, Kergna A, Kushwaha S, Musa S, Ntoukam G (2003). Cowpea supply and demand in West and Central Africa. Field Crops Research 82:215-231.

Mbiendou M (2012) Haricot niébé: L'or blancdu Sahel. La voix du PaysanMensuel del'entrepreneur rural.

Nei M(1987). Molecular evolutionary genetics. Columbia University Press.

Nielsen S, Ohler T, Mitchell C (1997). Cowpea leaves for human consumption: production, utilization, and nutrient composition. In:
Singh B, Mohan Raj D, Dashiell K, Jackai L (Eds). Advances in cowpea research. International Institute of Tropical Agriculture (IITA) and Japan International Research Center for Agricultural Sciences (JIRCASS), Ibadan, Nigeriapp 326-332.

Nkamleu B, Coulibaly O, Thyggard S, Tamo M (2000). Farmers and traders decision making in cowpea pest management in Western Highlands of Cameroon. World Cowpea Research Conference III, Ibadan, Nigeria.

Nkouannessi M (2005). The genetic, morphological and physiological evaluation of African cowpea genotypes. MSc Thesis, University of Free Statepp 131.

Ofori K, Kumaga FK, Tonyigah A (2006). Morphological characterization and agronomic evaluation of bambara groundnut (Vigna subterranea (L). Verd.) germplasm in Ghana. Plant Genetic Resources Newsletter 145:23-28.

Pasquet RS (2000). Allozyme diversity of cultivated cowpea Vigna unguiculata (L.) Walp. Theoretical and Applied Genetics 101:211-219.

Purseglove JW (1968). Tropical Crops-Dicotyledons. Longman Green and Co.Ltd.,London.

Rachie KO (1985). Introduction. In: Singh SR, Rachie KO (Eds). Cowpea research, production and utilization. Wiley, New York.

Rachie KO, Rawal KM (1976). Integrated approaches to improving cowpea, Vigna unguiculata (L.) Walp. Technical Bulletin No 5, IITA, Ibadan, Nigeria

Roy PS, Samall R, Rao GJN, Patnaik SSC, Jambhulkar NN, Patnaik A, Mohapatra T (2016). Differentiation and description of aromatic short grain rice landraces of eastern Indian state of Odisha based on qualitative phenotypic descriptors. BMCEcology 16:36.

Sharmar S, Upadhyaya HD, Rootkiwal M, Varshney RK, Gowda CLI (2013). Chickpea, In: Singh M, Upadhyaya HD, Bisht IS (Eds). Genetic and genomic resources of grain legume improvement. Elsevier, London, UKpp 81-104.

Singh BB, Emechebe AM (1997). Advances in research on cowpea, Striga and Alectra. In: Singh BB, Mohan Raj DR, Dashiell KE, Jackai LEN (Eds). Advances in cowpea research. Copublication of International Institute of Tropical Agriculture (IITA) and Japan International Research Center for Agricultural Sciences (JIRCAS), IITA, Ibadan, Nigeriapp 215-224.

Singh SP (2001). Broadening the genetic base of common beans cultivars: A review. CropScience 1:1659-1675.

Smith JSC, Smith OS (1989). The description and assessment of distances between inbred lines of maize: The utility of morphological, biochemical, and genetic descriptors and a scheme for the testing of distinctiveness between inbred lines. Maydica 34:151-161.

St.Clair JB, Howe GT (2011). Strategies for conserving forest genetic resources in the face of climate change. Turkish Journal of Botany 35:403-409.

Wilkes G (1983). Current status of crop plant germplasm. CRC Critical Review in Plant Science 1:133-181. 